\title{
INHERITED PROTEIN C AND PROTEIN S DEFICIENCY IN RENAL TRANSPLANT CANDIDATES OF SINDH PROVINCE, PAKISTAN
}

\author{
Muhammad Hanif Mengal ${ }^{1}$, Hina Abbas ${ }^{2}$, Kiran Aamir ${ }^{3}$, Aamir Ramzan ${ }^{4}$ \\ Departments of Pathology, ${ }^{1}$ Bolan University of Medical Sciences, Quetta, ${ }^{2}$ Dow Medical College, Dow \\ University of Health Sciences, Karachi, ${ }^{3}$ Liaquat University of Medical and Health Sciences, Jamshoro, ${ }^{4}$ Bilawal \\ Medical College, Liaquat University of Medical and Health Sciences, Jamshoro, Pakistan
}

\begin{abstract}
Background: Thrombophilia is a common risk factor for venous thromboembolism. The objective of this study was to determine prevalence of inherited protein $\mathrm{C}$ and protein $\mathrm{S}$ deficiency in renal transplant candidates of Sindh Province, Pakistan.

Material \& Methods: This cross-sectional study was conducted in Department of Pathology, Sindh Institute of Urology and Transplantation, Karachi, Pakistan from 16-10-2010 to 15-4-2011. 300 renal transplant candidates were selected. Candidates with acquired thrombotic disorders, women taking oral contraceptives and patients taking anti-coagulants during previous one week were excluded. Venous blood samples were collected before starting dialysis procedure or at least two days after last dialysis session. Platelet-poor plasma (PPP) was parted using plastic pipettes and protein $C$ and protein $S$ were processed on coagulation analyzer. Sex, age groups $(<40$ and $\geq 40$ years), presence of protein $C$ deficiency and presence of protein $S$ deficiency were nominal variables and analyzed by count and percentage along with population parameters.
\end{abstract}

Results: 300 renal transplant candidates included 199 (66.33\%) men and 101 (33.67\%) women and 238 (79.33\%) in age group $<40$ years and $62(20.67 \%)$ cases in age group $\geq 40$ years. Prevalence of protein $C$ deficiency was $6.66 \%(20 / 300)$ and of protein S deficiency was $4 \%$ (12/300). Prevalence of PC deficiency was higher in men $5.33 \%$ than women $1.33 \%$. Also prevalence of PS deficiency was higher in men $3.0 \%$ than women $1.0 \%$. Prevalence of PC deficiency was higher in age group $<40$ years $5.67 \%$ than $\geq 40$ years $1.0 \%$. Also prevalence of PS deficiency was higher in age group $<40$ years $3.33 \%$ than $\geq 40$ years $0.66 \%$.

Conclusion: More prolonged and follow-up studies are needed to define the true significance of deficiency of protein $\mathrm{C}$ and $\mathrm{S}$ (coagulation inhibitors) in post-transplant settings.

KEYWORDS: Thrombophilia, Protein C, Protein S, Protein C deficiency; Protein S deficiency; Venous Thromboembolism; Oral Contraceptives; Dialysis; End-stage Renal Disease; Renal Transplantation.

This article may be cited as: Mengal $\mathrm{MH}$, Abbas $\mathrm{H}$, Aamir K, Ramzan A. Inherited protein $\mathrm{C}$ and protein $\mathrm{S}$ deficiency in renal transplant candidates of Sindh Province, Pakistan. Gomal J Med Sci 2019; 17 (4): 117-22. https://doi.org/10.46903/gjms/17.04.1968

\section{INTRODUCTION}

Modern treatment for end-stage renal disease (ESRD) is kidney transplantation that has improved the quality of life and survival. Acute rejection of allograft is also reduced to a greater extent by use

\section{Corresponding Author:}

Dr. Hina Abbas

Assistant Professor, Department of Pathology, Dow Medical College, Dow University of Health Sciences Karachi, Pakistan

E-mail: hina.abbas@duhs.edu.pkm

Date Submitted: 13-10-2018

Date Revised: 20-06-2019

Date Accepted: $\quad 01-07-2019$ of immunosuppressants. Still thrombotic complications remain a constant and consistently growing obstacle for renal transplantation, responsible for early allograft loss. ${ }^{1,2}$ Identification of preventable risk factor (s) for thrombosis is crucial for improved survival and prevention of renal allograft complications. This can be achieved when patients at risk for venous thromboembolism are recognized. Advances in thrombophilia screening have made it possible to detect high risk cases at an early stage. ${ }^{3,4}$ Prevention of hypercoagulability can be done either by accurate pre transplantation screening for thrombophilia or by identification of patients at higher risk for developing deep vein thrombosis (DVT). ${ }^{5}$ Outcome of $1-3 \%$ renal transplant recipients is affected by early 
vascular thrombotic complications, arterial or venous thrombosis. These patients carry an increased risk of DVT and pulmonary embolism. ${ }^{6}$ Protein C (PC) \& Protein $S$ (PS) deficiencies are reported as most common risk factors for developing venous thromboembolism (VTE). ${ }^{7}$ The reported prevalence of arteriovenous thrombosis in ESRD patients with PC deficiency is $26.2 \%$, and with PS deficiency is 16.3 respectively. 8 ESRD patients with thrombophilia are more prone to develop graft loss and thrombosis. So, by diagnosing hypercoagulable states earlier in these patients, who are renal transplant candidates, we can reduce morbidity.

Currently no data is available in Pakistan on the frequency of protein $\mathrm{C}$ and protein $\mathrm{S}$ deficiency among renal transplant candidates. This Study will provide the magnitude of this problem thereby strategies could be made to minimize this morbidity. We expect that allograft thrombosis may be preventable in renal transplantation by prospective recognition of patients at increased risk for thrombosis. ${ }^{8}$

The objective of this study was to determine the frequency of PC \& PS deficiency in renal transplant candidates.

\section{Operational definitions:}

Protein C deficiency: "The normal protein $\mathrm{C}$ level in a healthy adult is approximately $65-135 \mathrm{IU} / \mathrm{dL}$ ". $\mathrm{PC}$ level below this reference value was labeled as protein C deficiency. ${ }^{9}$

Protein S deficiency: The reference range is greater than $73 \mathrm{U} / \mathrm{dL}$ for males and greater than $63 \mathrm{U} / \mathrm{dL}$ for females. PS level below the reference value was labeled as protein $\mathrm{S}$ deficiency. ${ }^{10}$

\section{MATERIALS AND METHODS}

Design, Settings \& Duration: This cross-sectional study was carried out at Sindh Institute of Urology and Transplantation (SIUT) from 16-10-2010 to 154-2011. The study protocol was approved by the Ethical Review Committee of the SIUT. Consent of patients was obtained before inclusion in the study.

Population \& Sampling (Size, Technique \& Selection): Sindh Institute of Urology and Transplantation is the first and largest health facility offering renal transplantation in Pakistan. Assuming population of 5,000 renal transplant candidates in Sindh province of Pakistan and assuming 6\% prevalence of protein $C$ deficiency in these patients, a sample size of 300 cases was calculated with $2.61 \%$ margin of error and
95\% confidence level using Raosoft ${ }_{\circledast}$ online sample size calculator. ${ }^{11}$ Sampling was through consecutive, non-probability technique. All renal transplant candidates were eligible. Candidates with acquired thrombotic disorders (hepatic disease or antiphospholipid syndrome), women taking oral contraceptives and patients taking any kind of anti-coagulant therapy during the previous one week were excluded.

Conduct of Procedure: Venous blood samples were collected before starting the dialysis procedure or at least two days after the last dialysis session. Platelet poor plasma (PPP) was prepared by centrifuging the samples at $3,000 \mathrm{rpm}(1,000 \mathrm{G}$ relative centrifugal force) for 15 minutes in a refrigerated $\left(4-6{ }^{\circ} \mathrm{C}\right)$ centrifuge. Plasma was separated using plastic pipettes and PT and APTT were processed in Sysmex CA 1500 , and aliquots of remaining plasma was immediately stored at $-80 \mathrm{C}$ until analysis at a later date. Samples for thrombophilia screening were processed on "STAGO compact" coagulation analyzer. Protein $\mathrm{C}$ was measured by immunoassay using the Asserachrom Protein C test kit (Diagnostica Stago Inc., Parsippany, NJ, USA). Protein S (total) was measured by one step enzyme immunoassay using the Asserachrom total protein $S$ kits (Diagnostica Stago Inc., Parsippany, NJ, USA).

Data Collection \& Analysis: The demographic variables (attributes) included sex (men \& women) and age groups ( $<40$ and $\geq 40$ years) and research variables included presence of protein $C$ deficiency (yes and no) and presence of protein $\mathrm{S}$ deficiency (yes and no). The data for all these variables was on nominal (binary) scale and hence analyzed by count and percentage for the sample. Population parameters for proportion are estimated as confidence interval $(\mathrm{Cl})$ at confidence level $(\mathrm{CL})$ of $80 \%$.

\section{RESULTS}

A sample of 300 renal transplant candidates included 199 (66.33\%) men and 101 (33.67\%) women and 238 (79.33\%) in age group < 40 years and 62 (20.67\%) cases in age group $\geq 40$ years.

The prevalence of protein C deficiency was 20/300 $(6.66 \%)$ and of protein S deficiency was 12/300 (4\%) in renal transplant candidates. Corresponding interval estimates for population (estimated population parameters) are given as confidence intervals (Cl) for proportion at $80 \%$ confidence level (CL). One $(0.33 \%)$ case of mixed deficiency was counted in PC deficiency for easy calculations. (Table 1)

Table 1: Frequency of Protein $C$ and Protein $S$ deficiency in renal transplant candidates population of Sindh Province, Pakistan $(n=300)$

\begin{tabular}{|l|c|c|c|c|}
\hline \multirow{2}{*}{ Variables } & \multicolumn{2}{|c|}{ Sample statistics } & \multicolumn{2}{c|}{$80 \%$ Cl for Proportion } \\
\cline { 2 - 5 } & Count & Percentage & Lower & Upper \\
\hline Presence of PC deficiency & 20 & $6.66 \%$ & $4.82 \%$ & $8.51 \%$ \\
\hline Presence of PS deficiency & 12 & $4.0 \%$ & $2.55 \%$ & $5.44 \%$ \\
\hline
\end{tabular}


Table 2: Distribution of Protein $C$ and Protein $S$ deficiency by sex in renal transplant candidates population of Sindh Province, Pakistan (=300)

\begin{tabular}{|l|c|c|c|c|c|c|}
\hline \multirow{2}{*}{ Research Variables } & \multirow{2}{*}{ Sex } & \multirow{2}{*}{ Sample size } & \multicolumn{3}{|c|}{ Sample statistics } & \multicolumn{2}{|c|}{$80 \%$ Cl for Proportion } \\
\cline { 4 - 7 } & & & Count & Percentage & Lower & Upper \\
\hline \multirow{2}{*}{ Presence of PC deficiency } & Men & 199 & 16 & 5.33 & 3.67 & 6.99 \\
\cline { 2 - 7 } & Women & 101 & 04 & 1.33 & 0.48 & 2.18 \\
\hline \multirow{2}{*}{ Presence of PS deficiency } & Men & 199 & 09 & 3.00 & 1.73 & 4.26 \\
\cline { 2 - 7 } & Women & 101 & 03 & 1.00 & 0.26 & 1.73 \\
\hline
\end{tabular}

Table 3: Distribution of Protein $\mathrm{C}$ and Protein $\mathrm{S}$ deficiency by age groups in candidates of renal transplants population of Sindh Province, Pakistan $(n=300)$

\begin{tabular}{|l|l|c|c|c|c|c|}
\hline \multirow{2}{*}{ Research Variables } & \multirow{2}{*}{ Age groups } & \multirow{2}{*}{ Sample size } & \multicolumn{3}{|c|}{ Sample statistics } & \multicolumn{2}{|c|}{$80 \% \mathrm{Cl}$ for Proportion } \\
\cline { 4 - 7 } & & & Count & Percentage & Lower & Upper \\
\hline \multirow{2}{*}{ Presence of PC deficiency } & $<40$ years & 238 & 17 & 5.67 & 3.95 & 7.38 \\
\cline { 4 - 7 } & $\geq 40$ years & 62 & 03 & 1.00 & 0.26 & 1.73 \\
\hline \multirow{2}{*}{ Presence of PS deficiency } & $<40$ years & 238 & 10 & 3.33 & 2.00 & 4.66 \\
\cline { 2 - 7 } & $\geq 40$ years & 62 & 02 & 0.66 & 0.06 & 1.26 \\
\hline
\end{tabular}

The distribution of PC deficiency and of PS deficiency by sex is shown in Table 2. The prevalence of PC deficiency was higher in men $5.33 \%$ than women $1.33 \%$. Also the prevalence of PS deficiency was higher in men $3.0 \%$ than women $1.0 \%$.

The distribution of PC deficiency and of PS deficiency by age groups is shown in Table 3. The prevalence of $\mathrm{PC}$ deficiency was higher in age group $<40$ years $5.67 \%$ than $\geq 40$ years $1.0 \%$. Also the prevalence of PS deficiency was higher in age group $<40$ years $3.33 \%$ than $\geq 40$ years $0.66 \%$.

\section{DISCUSSION}

Thrombophilia is a wider term for an imbalance of hemostasis that increases propensity to develop thrombosis along with the influencing factors which can be inherited, acquired or a blend of both. ${ }^{12}$ Among the genetic factors that are considered as risk factors for thrombosis included the deficiency of coagulation inhibitors like antithrombin (AT), protein $C(P C)$, protein $S$ (PS) and presence of factor $V$ Leiden mutation on prothrombin gene 20210A. These established hereditary factors predisposes a person to develop venous thrombosis and although infrequent but arterial thrombosis can also occur. ${ }^{13}$

End-stage renal disease (ESRD) is an established risk factor for arterial and venous thromboembolism (TE) ${ }^{14}$ Generally risk of thromboembolism is higher in patients with compromised renal function as compared to the normal person with kidney functioning normally. ${ }^{15}$ Presence of additional risk factors like surgery, malignancy or thrombophilia further increases the risk of thromboembolism in ESRD patients. ${ }^{16}$ In our study out of 300 renal transplant candidates, $32(10.66 \%)$ had anticoagulant deficiency. These deficiencies are mostly attributed to inherited defects; however acquired factors cannot be ignored. We attempted to eliminate the acquired factors by first excluding the patients on the basis of history and then by collecting sample two days prior to dialysis and without heparin administration. Significant number of patients with protein $\mathrm{C}$ and protein $\mathrm{S}$ deficiency in our study group cannot be clarified exclusively in this manner. Despite the efforts and attempts to eliminate the secondary factors, dialysis effect could not be completely excluded as all patients being renal transplant candidates were maintained on regular haemodialysis. Screening for anticoagulant factors which can predispose a person to hypercoagulability is highly recommended in patients undergoing hemodialysis and are potential candidate for renal transplant as a precautionary measure to decrease the risk of subsequent graft rejection. ${ }^{17}$

From literature review we see that the PC \& PS deficiencies are more common as well as stronger risk factors for thromboembolism as compared to antithrombin and factor $\mathrm{V}$ mutation and may be helpful in forecasting the risk of thromboembolism in Asians. ${ }^{18,19}$

In our study we found $6.66 \%$ patients had PC deficiency and $4.0 \%$ had PS deficiency. PC activity is seen to be diminished in patients who are maintained on regular hemodialysis due to the renal failure (acute or chronic). There are conflicting reports on the effects of dialysis on PC \& PS activity as with dialysis, the activity of these anticoagulants can be reduced or may remain unaffected. We tried to circumvent dialysis effect by collecting the sample two days prior to the dialysis. There is an inverse relationship demonstrated between the PC activity 
and serum creatinine levels. PC activity is also used in uremic samples.

Frequency of thrombophilia was found to be higher in a study conducted by Shoaib, et al. on 61 ESRD patients. They found $26.2 \%$ patients with PC deficiency and $16.3 \%$ patients with PS deficiency. Although their results exhibited much higher frequency of PC \& PS deficiency than our results but the sample proportion was totally different. ${ }^{20}$ Their study included diagnosed cases of VTE; in contrast we had asymptomatic ESRD patients in our sample. Ben Tal O, et al. evaluated 107 patients for 4 years to estimate the frequency of hereditary factors leading to thrombophilia and their results and frequencies were very much close to our results that is $5.6 \%$ and $2.8 \%$ patient had the deficiency of protein $\mathrm{C}$ and protein $\mathrm{S}$ respectively. ${ }^{21}$

A noteworthy observation in our study was the detection of PC \& PS deficiency being more frequent in patients younger than 40 years of age. Overall, $27(9 \%)$ patients with anticoagulant deficiency were aged less than 40 years against $5(1.66 \%)$ patients $\geq 40$ years. One reason which is evident from our study that we have more patients included in study aged less than 40 years, probably because mostly young patients were satisfying the criteria and experiencing renal transplantation.

Genetic factors are more important in VTE in young individuals while risk of VTE in older population is mostly related to acquired causes of hypercoagulability states, among which immobility with advanced age is an important contributing factor. Our findings are supported by another study which demonstrates 1.92 fold higher probability of diagnosing thrombophilia among patients with their first VTE diagnosed under age of 40 years but the patient population was different as the study was conducted on diagnosed VTE cases, while in our population we screened renal transplant candidates beforehand and prior to any episode of TE. ${ }^{22}$ Another study conducted by Lee SY, et al. also found that thrombophilia was most frequently detected in patients less than 40 years of age as compared to older patients but this study was specifically conducted on patients who had unprovoked VTE while we conducted study on asymptomatic renal transplant candidates. ${ }^{23}$

We found a scarcity of data on prevalence of thrombophilia with respect to age and gender. A study conducted by Paschôa, et al. in 2006 included 84 patients with history of VTE and screened them for thrombophilia. In this study there was no difference in prevalence of thrombophilia among patients below or above 50 years of age.$^{24} \mathrm{In}$ the presence of genetic factors the chances of developing VTE at a younger age increases from 5 to 80 fold.

In our study PC \& PS deficiency was found in 25 (8.33\%) men against seven (2.33\%) women, however going through literature we found that data related to gender differences in prevalence of thrombophilia is scarce and despite the fact that the female patients are progressively inclined to develop VTE in light of the consuming oral contraceptive pills and hormonal impacts, yet the numerous studies so far failed to locate any steady contrasts in rate of VTE among male and the female. ${ }^{25}$ Similar incidents in both sexes were found by Anderson, et al. ${ }^{26}$

Chen, et al. in a case control study in Chinese population didn't find any gender specific effect; rather an age specific difference was achieved. ${ }^{27} \mathrm{~A}$ study conducted by Sakata, et al. on a large cohort of 2690 blood donors, they found a prevalence of PS deficiency in $1.12 \%$ to be present in male and $1.60 \%$ in females which they thought may be misrepresented because of the hormonal impact. ${ }^{28}$ In another study Silverstein, et al. noted a slightly higher incidence in females of young age. Cushman, et al. has also reported again the similar incidence of VTE among both genders. ${ }^{29,30}$ In our study we found a higher prevalence of anticoagulant deficiency in male population as compared to female; the reason might be the fact that there were more male included in our sample which in turn may be attributed to the element that more number of males undergo renal transplantation as they are more likely to suffer from ESRD because of several reasons that are not required to be mentioned here. This is shown in a study report of United States in 2011 which displays a higher frequency of ESRD in male when contrasted with female. ${ }^{31}$

\section{CONCLUSIONS}

1. In this study, Protein $C$ and Protein $S$ deficiency were common findings in ESRD patients, candidates for renal transplant.

2. Protein $\mathrm{C}$ deficiency was more common than Protein $\mathrm{S}$ deficiency.

3. The results of Protein $\mathrm{C}$ and Protein S screening may aid in further stratifying venous thromboembolism risk after exposure to a known risk factor i.e. organ transplant surgery.

4. Doctors must take into consideration Protein $C$ and Protein S level in ESRD patients so as to know their coagulation that would give an idea for appropriate anticoagulation therapy and should review the best modifier for renal transplant of each patient

5. More prolonged and follow-up studies are needed to define the true significance of deficiency of protein $\mathrm{C}$ and $\mathrm{S}$ (coagulation inhibitors) in post-transplant settings.

\section{REFERENCES}

1. Hoffbrand AV, Moss PA. Thrombosis and antithrombotic therapy. In: Hematology. 6th ed. Oxford: Wiley-Blackwell; 2011.p. 363-80.

2. Tasneem RA, Kaleem M, Butt MK, Zaheer K, 
Ashraf HS. Experience of renal transplantation. Ann King Edward Med Uni 2000 Oct-Dec; 6(4): 374-5.

3. Dick AA, Lerner SM, Boissy AR, Farrell CE, Alfrey EJ. Excellent outcome in infants and small children with thrombophilias undergoing kidney transplantation. Pediat Transplant 2005 Feb; 9(1): 39-42. https://doi.org/10.1111/j.13993046.2004.00232.x

4. Heit JA. Thrombophilia: common questions on laboratory assessment and management. Hematology Am Soc Hematol Educ Program 2007; 127-35. https://doi.org/10.1182/asheducation-2007.1.127

5. John U, Ken touché K, Nowak G, Schubert, Miseluitz J. Successful renal transplantation in a patient with heterozygous prothrombin gene, factor $\mathrm{V}$ leiden mutation and heparin induced thrombocytopenia using r-hirudin as anticoagulant. Pediat Transplant 2006; 10: 114-8. https:// doi.org/10.1111/j.1399-3046.2005.00398.x

6. Todeschini P1, La Manna G, Dalmastri V, Feliciangeli G, Cuna V, Montanari M. Incidence of late deep venous thrombosis among renal transplant patients. Trans Proc 2013;45(7):2666-8. https:// doi.org/10.1016/j.transproceed.2013.07.017

7. Shen MC, Lin JS, Tsay W. High prevalence of antithrombin III, protein $\mathrm{C}$ and protein $\mathrm{S}$ deficiency, but no factor $\mathrm{V}$ Leiden mutation in venous thrombophilic Chinese patients in Taiwan. Thromb Research 1997 Aug 15;87(4):377-85. https://doi. org/10.1016/S0049-3848(97)00141-2

8. Nampoory MR, Das KC, Johny KV, Al-Hilali N, Abraham M, Easow S, et al. Hypercoagulability, a serious problem in patients with ESRD on maintenance haemodialysis, and its correction after kidney transplantation. Am J Kidney Dis 2003; 42: 797-805. https://doi.org/10.1016/S02726386(03)00860-6

9. Pai A. Protein C. Medscape [updated 2014 Jan 15, accessed 2018, Aug 12]. Available at https:// emedicine.medscape.com/article/2085992-overview

10. Pai A. Protein S. Medscape [updated 2014 Jan 15, accessed 2018, Aug 12]. Available at: https:// emedicine.medscape.com/article/2086014-overview

11. Raosoft $\circledast$ sample size calculator [internet]. Seattle, WA, USA: Raosoft Inc.; 2004. [accessed 2018 Jan 13]. Available at: http://www. raosoft. com/samplesize.html

12. Dugalic S, Petronijevic M, Stefanovic A, Stefanovic K, Perovic M, Pantic I, et al. Perinatal complications related to inherited thrombophilia: review of evidence in different regions of the world. J Maternal-Fetal Neonat Med 2019 Sep 23: https://doi.org/10.1080/14767058.2019.1669017

13. Srivastava $S$. Understanding genetic variations as risk factors for development venous thrombo-embolism (VTE). Adv Genet Eng 2016; 5(2):2-7. https://doi.org/10.4172/2169-0111.1000143
14. Bauer A, Limperger V, Nowak-Göttl U. End-stage renal disease and thrombophilia. Hämostaseologie 2016; 36 (02): 103-7. https://doi.org/10.5482/ HAMO-14-11-0063

15. Rattazzi M, Villalta S, De Lucchi L, Sponchiado A, Galliazzo S, Faggin E, et al. Chronic kidney disease is associated with increased risk of venous thromboembolism recurrence. Thromb Research 2017 Dec 1; 160: 32-7. https://doi.org/10.1016/j. thromres.2017.10.011

16. Lu HY, Liao KM. Increased risk of deep vein thrombosis in end-stage renal disease patients. BMC Nephrol 2018 Dec 1;19(1):204. https://doi. org/10.1186/s12882-018-0989-Z

17. Sarı F, Taşkapan H, Sığırcı A, Akpınar B. Evaluation of risk factors for arteriovenous fistula failure in patients undergoing hemodialysis. Erciyes Med J 2016 Mar 1; 38(1). 12-9. https://doi.org/10.5152/ etd.2016.0052

18. Mannucci PM, Franchini M. Classic thrombophilic gene variants. Thromb Haemost 2015; 114(5): 885-9. https://doi.org/10.1160/TH15-02-0141

19. Satpanich $P$, Rojnuckarin P. Risk factors for venous thromboembolism (VTE) recurrences in Thai patients without cancer. Hematology 2019 Jan 1;24(1):159-65. https://doi.org/10.1080/102453 32.2018.1535535

20. Shoaib M, Shamsi TS, Naz A. Arteriovenous thrombosis in chronic renal failure patients receiving renal replacement therapy. J College Physicians Surg Pak 2008 Jul 1; 18(7):418-23.

21. Ben-Tal O, Zivelin A, Seligsohn U. The relative frequency of hereditary thrombotic disorders among 107 patients with thrombophilia in Israel. Thromb Haemost 1989 Feb; 61(1): 50-4. https:// doi.org/10.1055/s-0038-1646525

22. Weingarz L, Schwonberg J, Schindewolf M, Hecking $\mathrm{C}$, Wolf $Z$, Erbe M, et al. Prevalence of thrombophilia according to age at the first manifestation of venous thromboembolism: results from the MAISTHRO registry. British J Haematol 2013 Dec; 163(5): 655-65. https://doi.org/10.1111/bjh.12575

23. Lee SY, Kim EK, Kim MS, Shin SH, Chang H, Jang SY, et al. The prevalence and clinical manifestation of hereditary thrombophilia in Korean patients with unprovoked venous thromboembolisms. PloS One 2017 Oct; 12(10): e0185785. https:// doi.org/10.1371/journal.pone.0185785

24. Paschôa AF, Guillaumon AT. Impact of screening on thrombophilia for patients with venous thrombosis. Int Angiol 2006 Mar ;25(1):52-9.

25. White $\mathrm{RH}$. The epidemiology of venous thromboembolism. Circulation 2003 Jun 17; 107(23 Suppl 1): 14-8. https://doi.org/10.1161/01. CIR.0000078468.11849.66

26. Anderson FA Jr., Wheeler HB, Goldberg RJ, Hosmer DW, Patwardhan NA, Jovanovic B, et al. A population-based perspective of the hospital incidence and case-fatality rates of deep vein thrombosis and pulmonary embolism. The Worcester DVT Study. Arch Intern Med 1991 May; 151(5): 933-8. https://doi.org/10.1001/archinte.151.5.933 
27. Chen WH, Lan MY, Chang YY, Chen SS, Liu JS. The prevalence of protein $\mathrm{C}$, protein $\mathrm{S}$, and antithrombin III deficiency in non-APS/SLE Chinese adults with noncardiac cerebral ischemia. Clin Appl Thromb Hemost 2003 Apr; 9(2): 155-62. https://doi.org/10.1177/107602960300900211

28. Sakata T, Okamoto A, Mannami T, Tomoike H, Miyata T. Prevalence of protein S deficiency in the Japanese general population: the Suita Study. J Thromb Haemost 2004 Jun; 2(6): 1012-3. https:// doi.org/10.1111/j.1538-7836.2004.00742.x

29. Silverstein MD, Heit JA, Mohr DN, Petterson TM, O'Fallon WM, Melton 3rd LJ. Trends in the incidence of deep vein thrombosis and pulmonary embolism: a 25-year population-based study. Arc Intern Med 1998 Mar 23; 158(6): 585-93. https:// doi.org/10.1001/archinte.158.6.585

30. Cushman M, Tsai A, Heckbert SR, White R, Rosamund W, Enright $P$, et al. Deep vein thrombosis and pulmonary embolism in two cohorts: the longitudinal investigation of thromboembolism etiology. Am J Med 2004 Jul 1; 117(1): 19-25. https://doi.org/10.1016/j.amjmed.2004.01.018

31. US Renal Data System: Reference tables D.6 and D.9. In: 2018 USRDS Annual Data Report: Epidemiology of kidney disease in the United States, Bethesda, MD. National Institutes of Health, National Institute of Diabetes and Digestive and Kidney Diseases, 2018 [accessed 2018 October 25]. Available at: https://www.usrds.org/ reference.aspx

CONFLICT OF INTEREST
Authors declare no conflict of interest.
GRANT SUPPORT AND FINANCIAL DISCLOSURE
None declared.

\section{AUTHORS' CONTRIBUTION}

The following authors have made substantial contributions to the manuscript as under:

Conception or Design: $\quad$ MHM, HA

Acquisition, Analysis or Interpretation of Data: $\quad$ MHM, HA, HA, AR

Manuscript Writing \& Approval: $\quad$ MHM, HA, HA, AR

All the authors agree to be accountable for all aspects of the work in ensuring that questions related to the accuracy or integrity of any part of the work are appropriately investigated and resolved. 